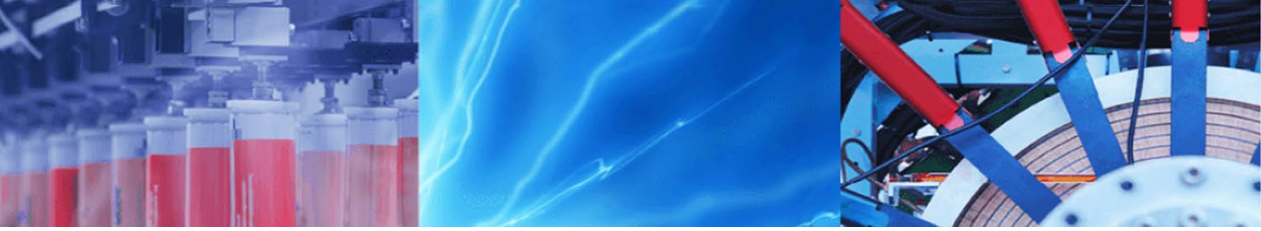

Research Article

\title{
Characterization and mapping of hematite ore mineral classes using hyperspectral remote sensing technique: a case study from Bailadila iron ore mining region
}

\author{
Ibrahim Shaik $^{1}$ - S. K. Begum ${ }^{2}$ P. V. Nagamani ${ }^{1}$ Narayan Kayet ${ }^{3}$
}

Received: 21 October 2020 / Accepted: 12 January 2021 / Published online: 23 January 2021

(c) The Author(s) 2021 OPEN

\begin{abstract}
The study demonstrates a methodology for mapping various hematite ore classes based on their reflectance and absorption spectra, using Hyperion satellite imagery. Substantial validation is carried out, using the spectral feature fitting technique, with the field spectra measured over the Bailadila hill range in Chhattisgarh State in India. The results of the study showed a good correlation between the concentration of iron oxide with the depth of the near-infrared absorption feature $\left(R^{2}=0.843\right)$ and the width of the near-infrared absorption feature $\left(R^{2}=0.812\right)$ through different empirical models, with a root-mean-square error (RMSE) between $<0.317$ and $<0.409$. The overall accuracy of the study is $88.2 \%$ with a Kappa coefficient value of 0.81 . Geochemical analysis and X-ray fluorescence (XRF) of field ore samples are performed to ensure different classes of hematite ore minerals. Results showed a high content of $\mathrm{Fe}>60 \mathrm{wt} \%$ in most of the hematite ore samples, except banded hematite quartzite (BHQ) $(<47 \mathrm{wt} \%)$.
\end{abstract}

Keywords Hyperspectral remote sensing $\cdot$ Spectral feature fitting $\cdot$ Spectral angle mapper $\cdot$ XRF

\section{Introduction}

Developments in hyperspectral remote sensing technology enable mapping of various geological and lithological structures and identification of different minerals [1, 2], including altered minerals like kaolinite, montmorillonite, illite, dickite, aluminite, feldspar, etc., and different types of iron ores like hematite, magnetite, and goethite [3]. Each mineral exhibits unique absorption and spectral reflectance pattern in the electromagnetic spectrum, which allows the identification of every element, and relative abundance in the rock sample for any given location. For instance, spectral absorption in the visible and nearinfrared (VNIR) region gives essential information about iron oxides [4]. $\mathrm{Fe}^{2+}$ ion contained in rocks is accountable for absorption at a wavelength of nearly 900 to $1100 \mathrm{~nm}$, and $\mathrm{Fe}^{3+}$ ion sources for absorption at $750 \mathrm{~nm}-870 \mathrm{~nm}$ wavelength regions. Material having an utmost quantity of iron content shows higher reflectance phenomena at a wavelength portion of $870 \mathrm{~nm}$ [5]. VNIR and shortwave infrared (SWIR) wavelength bands are very useful for lithological mapping, identifying hydrothermally altered minerals, and differentiating oxide and hydroxide minerals in high-terrain regions, differentiating various types of carbonate lithologies such as limestone karst and hydrothermal dolomites [6]. The transition of electrons between different transition metals like iron ( $\mathrm{Fe})$, manganese $(\mathrm{Mn})$, and chromium $(\mathrm{Cr})$ is associated with the reflectivity of multiple minerals in VNIR and SWIR spectral bands [7]. In this background, the present study is taken up to map different types of hematite ore minerals in the Bailadila mines situated in the southernmost part of Chhattisgarh State, India, using EO-1 Hyperion data.

$\triangle$ Ibrahim Shaik, ibrahimshaik.1985@gmail.com | ${ }^{1}$ National Remote Sensing Centre, Hyderabad, India. ${ }^{2}$ Department of Geophysics, Andhra University, Visakhapatnam, India. ${ }^{3}$ Department of Mining Engineering, Indian Institute of Technology, Kharagpur, India. 


\section{Study area}

Bailadila mining area is the first enormous open-cast iron ore mine in India, located in Dantewada District, Chhattisgarh State, between $18^{\circ} 35^{\prime} 48^{\prime \prime}$ and $18^{\circ} 38^{\prime} 30^{\prime \prime} \mathrm{N}$ latitude and $81^{\circ} 13^{\prime} 22^{\prime \prime}$ and $81^{\circ} 16^{\prime} 00^{\prime \prime}$ E longitude, covering in Survey of India (SOI) toposheet no. 65F/1, F/2, F/5, and F/6. Bailadila hill range extends $40 \mathrm{~km}$ in length and $4 \mathrm{~km}$ in width, and this range is the highest point (1276 m MSL) within Chhattisgarh State (Fig. 1).

The generalized geological succession in the Bailadila hill range after [8] as mentioned in [9] and [10] is shown in Table 1. The Bailadila meta-sedimentary sequence unconformable overlies the older metamorphic of Bengpal Group with intervening post-Bailadila granites $[10,11]$. This meta-sedimentary in the area forms two approximately parallel $\mathrm{N}-\mathrm{S}$ trending ridges, extending about $30 \mathrm{~km}$ from Kirundul in the south to Jhirka in the north, where they confluence and extend further northward [8]. The sequence exposed on the eastern flank of the east ridge forms as an east-dipping overturned limb of an isoclinal syncline. The western ridge is also a synclinal ridge, with near-vertical to steeply eastward dipping beds. The phyllites and conglomerates occupying the intervening valley are the sequences in the area that form a northerly plunging synclinorium $[8,11]$. The regional strike of the main Bailadila range is $\mathrm{N}-\mathrm{S}$ with steep easterly dips. The Bailadila range consists of two high ranges separated by a valley. Crookshank H. [8] identified two lightly folded overturned synclines for the two ridges and as eroded anticline occupying the valley in between. The main fold has been superimposed by two sets of easterly and northwesterly cross-folds. The geological map of the study area is shown in Fig. 2 .
Fig. 1 Location of the study area: a India, b Chhattisgarh State, c Dantewada District, and $\mathbf{d}$ Bailadila iron ore mining region covered in Hyperion imagery
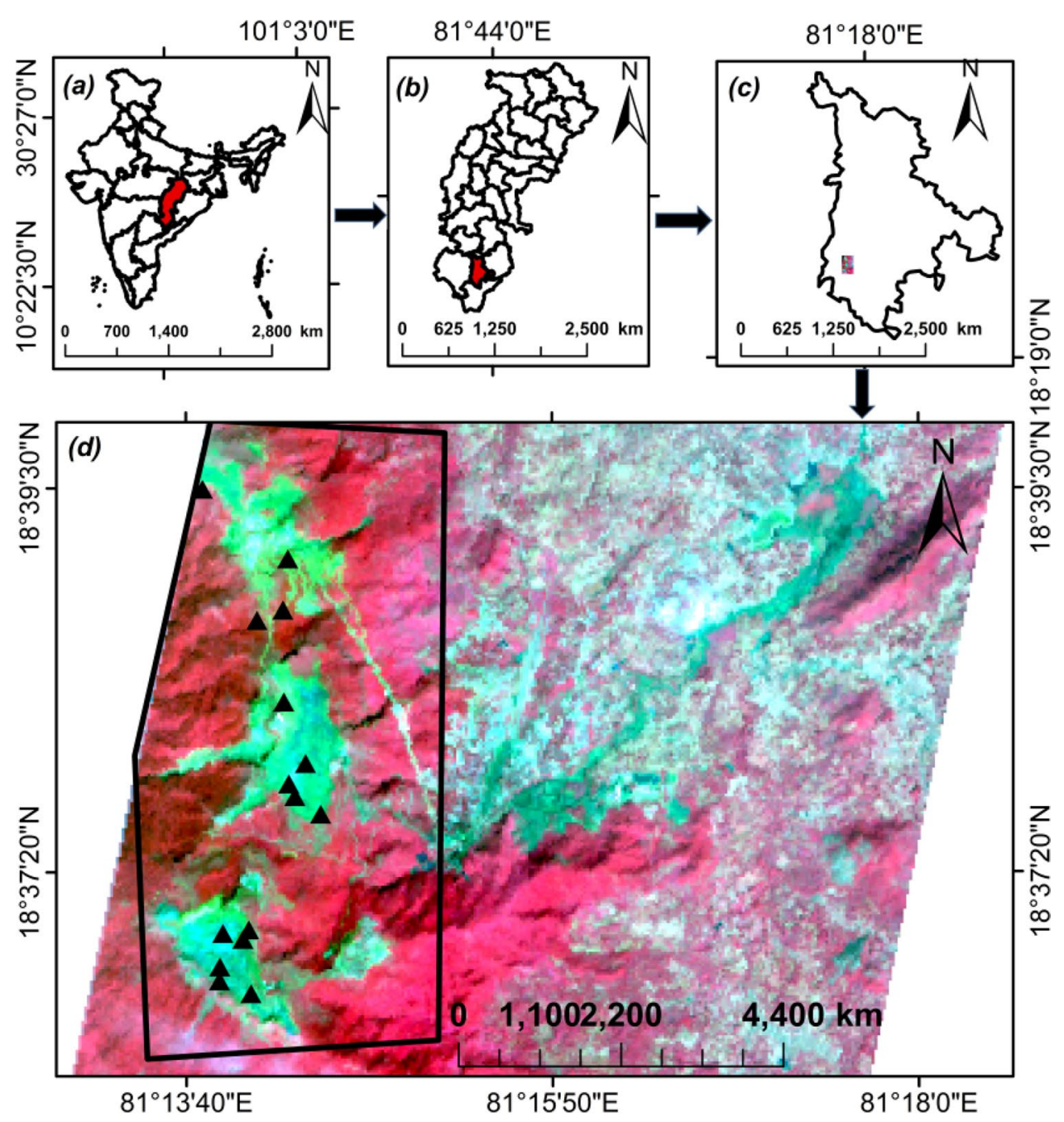

Study area $\boldsymbol{\Delta}$ Sample location 
Table 1 Geological succession of the study area [10]

\begin{tabular}{ll}
\hline Proterozoic Archean & \\
\hline Recent & Soils and alluvium laterite \\
\hline Unconformity & \\
Cuddapah (Purana) & Lime stone, shales, slate \\
& Sandstone and slates, quartzite, grits, conglomerates \\
Unconformity & Dolerite, pegmatite \\
Igneous rocks & Charnockite series \\
& Granite \\
& Greenstones \\
& Granitic gneisses and pegmatite \\
& Banded hematite quartzites and iron ores \\
& Grunerite quartzites, chloritic ferruginous \\
Bailadila iron ore series & Phyllites, carbonaceous shales \\
& White quartzites \\
Basement not exposed & Ferruginous schists, schistose conglomerates \\
Unconformity & Basalt and tuffs \\
Bengpal series & Andalusite phyllites, schists, gneisses, and quartzites \\
& Grunerite-garnet schists, BHQ, garnet-andalusite quartzites \\
Sukma series & Sericite quartzites and sandstones \\
& Sillimanite quartzite \\
& Magnetite quartzite, grunerite schists \\
& Diopside gneiss \\
& Cordierite-biotite gneisses, cordierite-anthophyllite rocks \\
& \\
\hline & \\
& \\
&
\end{tabular}

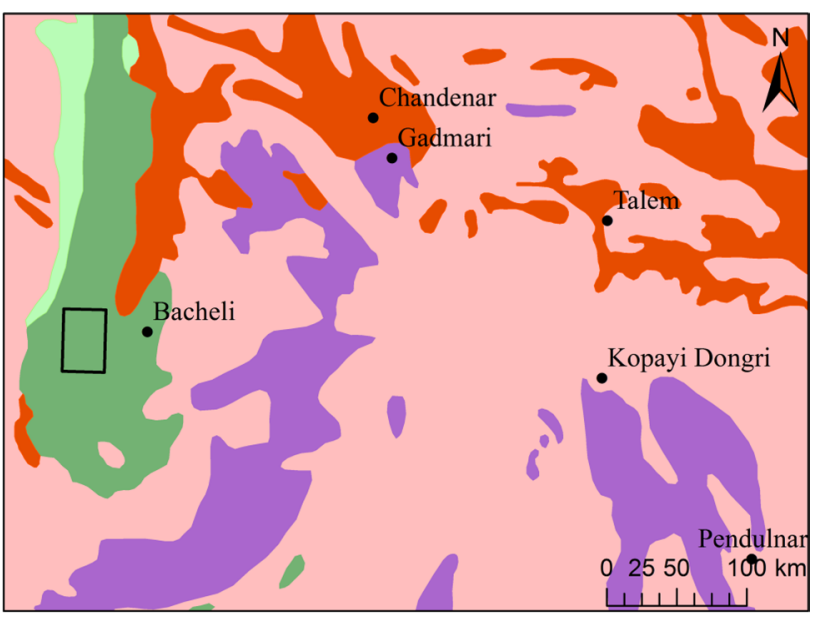

Legend

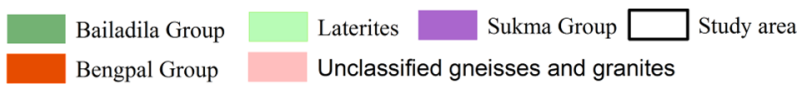

Fig. 2 Geological map of the study area

\section{Methods of study}

For this study, Hyperion (EO-1) satellite imagery with a spatial resolution of $30 \mathrm{~m}$ dated December 9,2009 , covering Bailadila hill rage was used to map the hematite ore minerals, substantial with spectral signatures of ore samples collected using ASD field spectroradiometer. Hyperion level-1R satellite data product with 242 spectral bands was downloaded from the USGS official Web site (https://earthexplorer.usgs.gov/), and the data were processed using Digital Image Processing software (Fig. 3). Initially, Hyperion data were preprocessed to remove the bad bands, vertical lines, and other lightening effects. The resized and processed data are atmospherically corrected to minimize the atmospheric influence caused by aerosols and other constituents present in the atmosphere. Spectra of various hematite ore classes extracted from the satellite imagery were analyzed using field-based spectra collected at appropriate locations with the help of the Global Positioning System (GPS). Field spectra of various hematite ore samples have been collected at different locations and processed to eliminate the temperature drift and water 
Fig. 3 Flowchart of the methodology adopted in the study

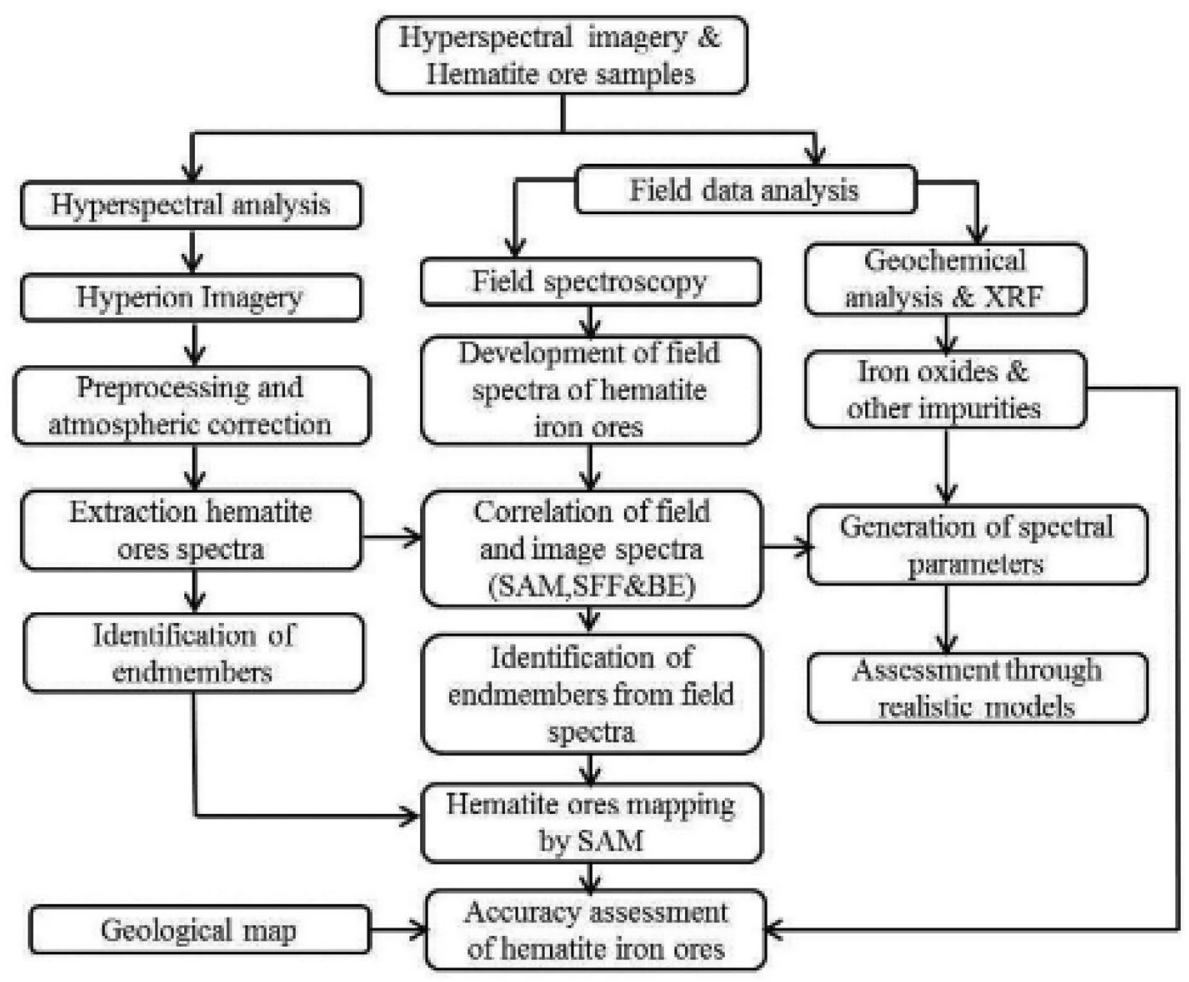

vapor absorption effects before using them for analysis. Spectral analyst techniques were used to correlate the similarity between image and field spectrum after continuum removal. Significantly matched image spectra were used as endmembers for mapping various hematite ore classes using the SAM algorithm. Geochemical and XRF analyses have been performed to ensure the amount of iron content present in the ore samples at respective locations. The accuracy of the map is assessed using the confusion matrix method and also through spectral similarity between image and field spectra using statistical spectral feature fitting techniques.

\section{Results and discussion}

\subsection{Data processing}

The foremost aim of preprocessing is to minimize geometric distortions, atmospheric, and solar flux effects of the data. This task is achieved through digital image processing techniques to convert spatial data into meaningful information. The most crucial step involves the removal of bands with no information from the data. The list of bands which are removed from the dataset is (1-7 and 225-242) non-illuminated, (58-78) for overlap region, (120-132, and 165-182 and 221-224) for water vapor absorption band, and (185-187) identified noise band. Therefore, 86 spectral bands are eliminated, and only 156 spectral bands are processed for utilization. The geometric correction of datasets is achieved through a suitable geo-referencing process. A cross-track illumination correction tool is used to rectify vegetation effects, device effects, scanning, and other lightening effects of imagery [12]. While processing, it is observed that data contain vertical black strip lines due to inaccurate standardization of discrete sensors on the raiment. This unresolved striping effect in the data can lead to a poor understanding of the result. The stripping effect is removed after applying wavelet Fourier adaptive filtering directly in the image domain [13] (Fig. 4).

\subsection{Atmospheric correction}

The significant and critical step of processing hyperspectral data is to convert the radiance to reflectance called an atmospheric correction. Fast Line-of-sight Atmospheric Analysis of Spectral Hypercubes (FLAASH) tool is an effective meteorological physics-based model, and this correction model is utilized for atmospheric correction [14]. The following parameters are used in the atmospheric correction module: atmospheric model: (selected based on seasonal latitude surface temperature model) tropical model is used for this purpose; water retrieval technique: for retrieving water amount for each pixel at $1135 \mathrm{~nm}$ water absorption feature. 2-band (K-T) as an aerosol retrieval model; rural as an aerosol model; and DISORT 

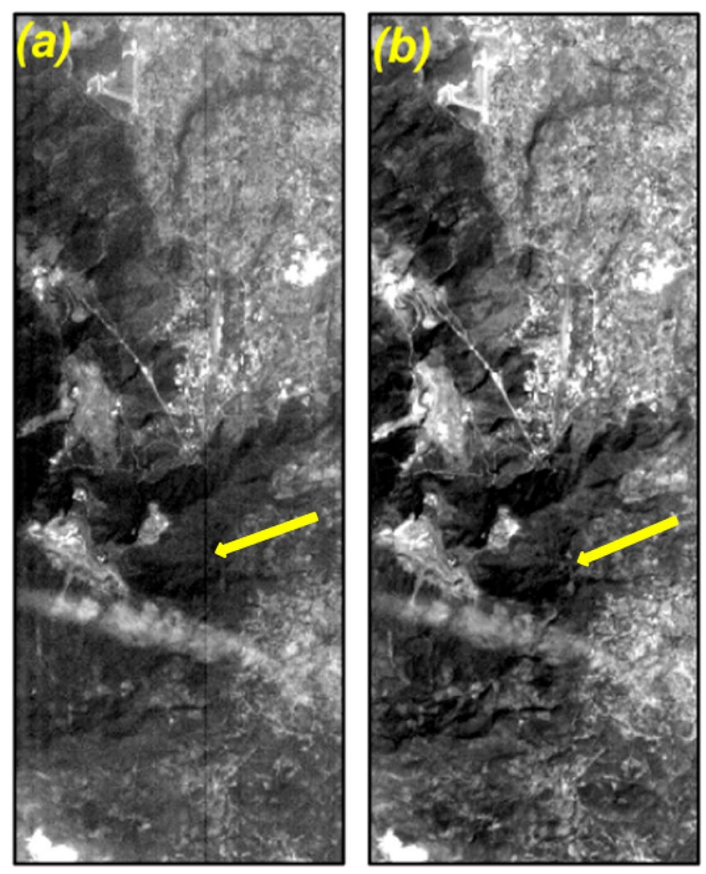

Fig. 4 Hyperion imagery $\mathbf{a}$ before and $\mathbf{b}$ after removal of stripping effect

as moderate-resolution transmittance multi-scatter model at a resolution of $15 \mathrm{~cm}^{-1}$ [15]. Accurate wavelength calibration is critical for atmospherically correcting Hyperion (EO-1) data. Spectral radiance at a sensor is calculated with the use of the following arithmetic equation (Eq. (1)) [16]:

$L=\left(\frac{A P}{1-p e S}\right)+\left(\frac{B p e}{1-p e S}\right)+L a$

where $L$ is the device spectral radiance; $\mathrm{P}$-surface reflectance of the pixel; $P e-$ mean of average surface reflectance for the pixel and an adjacent part; S-spherical albedo of the atmosphere; $L a$-radiance backscattered by the atmosphere; and $\mathrm{A}$ and $\mathrm{B}$-coefficients which depend on atmospheric and geometric condition. An atmospherically corrected spectrum is shown in Fig. 5.

\subsection{Comparison of image spectra and ground truth data}

Hyperspectral data consist of noise in the form of spikes and artifacts, and these are removed from the imagery during preprocessing, before the extraction of information of features in the form of spectra. Based on field spectral signatures collected at different sites, the corresponding pixel locations are recognized using ground coordinates (Table 2). The obtained iron ore samples are uniformly distributed to represent the entire mining area in the image. It is observed that the sample locations cover all the types of hematite iron ores (gray hematite, blue hematite, laminated ore, lateritic ore, and banded hematite quartzite). The sampling sites are identified in such a way that the buffering area equal to spatial resolution $(30 \mathrm{~m} \times 30 \mathrm{~m})$ is enclosed by a single type of ore in the targeted mining locations. The spectra extracted from Hyperion imagery for recognized sites are representing various classes of hematite iron ores within the research area (Fig. 1).

\subsection{Spectral response of hematite ore samples}

Hyperion reflectance spectra of five different hematite ores are shown in Fig. 6. To distinguish the variations in the depth of major absorption bands present in hematite ore spectra on a per-pixel basis, to normalize the curves continuum removal method was applied, to isolate the features, and to allow their comparison from a common baseline. A complete explanation of the continuum removal method is given by [17]. It is observed that different hematite ore samples have absorption between 750 and $1100 \mathrm{~nm}$ due to the presence of iron oxide; the depth of absorption spectrum increases with the increasing
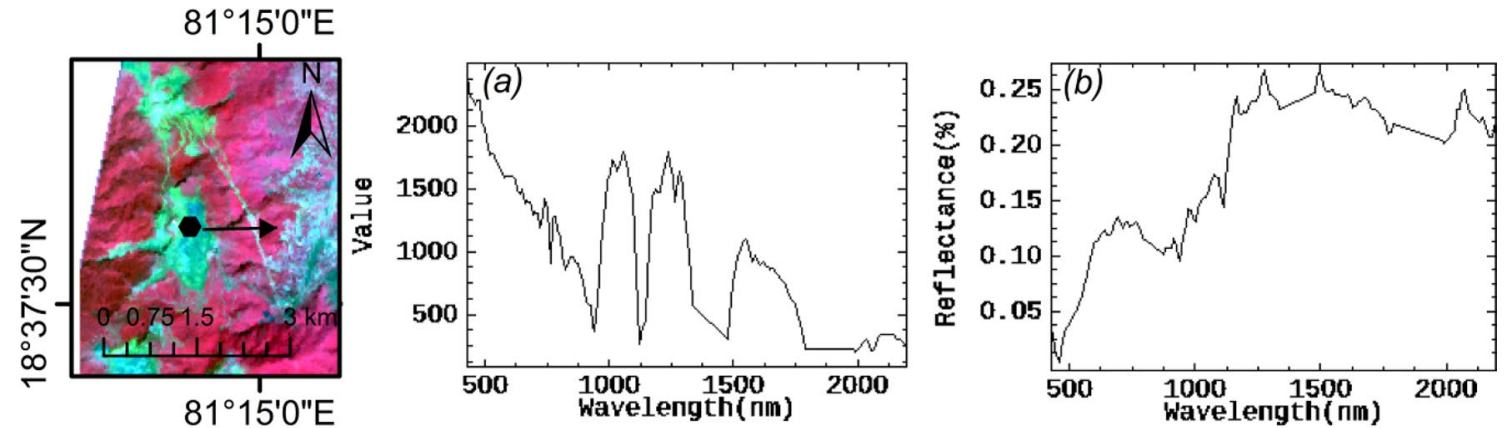

Location of collected spectra

Fig. 5 Image spectra $\mathbf{a}$ before and $\mathbf{b}$ after atmospheric correction 
Table 2 The locations of field samples collected

\begin{tabular}{llll}
\hline Sample no. & Description & \multicolumn{2}{l}{ Location } \\
\cline { 3 - 4 } & & Latitude (N) & Longitude (E) \\
\hline 1 & Gray hematite & $18^{\circ} 36^{\prime} 57.3^{\prime \prime}$ & $81^{\circ} 13^{\prime} 52.9^{\prime \prime}$ \\
2 & Blue hematite & $18^{\circ} 36^{\prime} 57.29^{\prime \prime}$ & $81^{\circ} 14^{\prime} 0.03^{\prime \prime}$ \\
3 & Laminated ore & $18^{\circ} 36^{\prime} 38.84^{\prime \prime}$ & $81^{\circ} 14^{\prime} 2.87^{\prime \prime}$ \\
4 & Lateritic ore & $18^{\circ} 37^{\prime} 0.47^{\prime \prime}$ & $81^{\circ} 14^{\prime} 2.08^{\prime \prime}$ \\
5 & BHQ & $18^{\circ} 36^{\prime} 47.93^{\prime \prime}$ & $81^{\circ} 13^{\prime} 51.83^{\prime \prime}$ \\
6 & BHQ & $18^{\circ} 38^{\prime} 17.7^{\prime \prime}$ & $81^{\circ} 14^{\prime} 14.64^{\prime \prime}$ \\
7 & Gray hematite & $18^{\circ} 37^{\prime} 56.84^{\prime \prime}$ & $81^{\circ} 14^{\prime} 22.29^{\prime \prime}$ \\
8 & Blue hematite & $18^{\circ} 37^{\prime} 39.68^{\prime \prime}$ & $81^{\circ} 14^{\prime} 27.66^{\prime \prime}$ \\
9 & Laminated ore & $18^{\circ} 37^{\prime} 32.67^{\prime \prime}$ & $81^{\circ} 14^{\prime} 16.66^{\prime \prime}$ \\
10 & Lateritic ore & $18^{\circ} 37^{\prime} 36.64^{\prime \prime}$ & $81^{\circ} 14^{\prime} 12.61^{\prime \prime}$ \\
11 & BHQ & $18^{\circ} 38^{\prime} 48.77^{\prime \prime}$ & $81^{\circ} 14^{\prime} 14.35^{\prime \prime}$ \\
12 & Gray hematite & $18^{\circ} 39^{\prime} 30.14^{\prime \prime}$ & $81^{\circ} 13^{\prime} 40.4^{\prime \prime}$ \\
13 & Blue hematite & $18^{\circ} 39^{\prime} 29.71^{\prime \prime}$ & $81^{\circ} 13^{\prime} 45.8^{\prime \prime}$ \\
14 & Laminated ore & $18^{\circ} 38^{\prime} 45.34^{\prime \prime}$ & $81^{\circ} 14^{\prime} 5.13^{\prime \prime}$ \\
15 & Lateritic ore & $18^{\circ} 39^{\prime} 36.25^{\prime \prime}$ & $81^{\circ} 13^{\prime} 41.98^{\prime \prime}$ \\
\hline
\end{tabular}

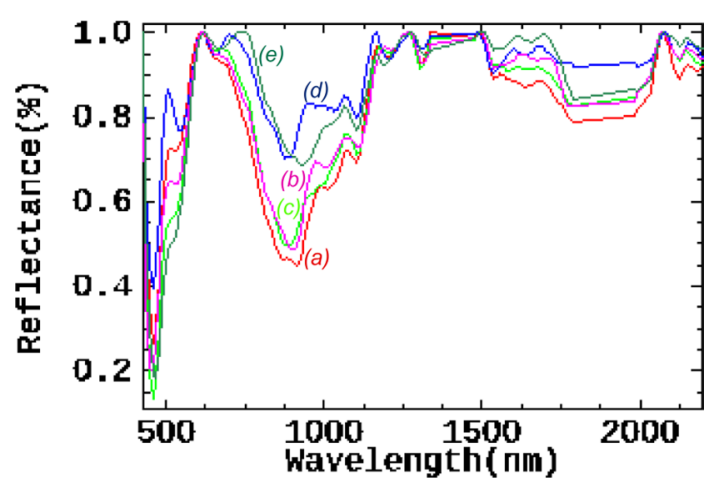

Fig. 6 Image reflectance spectra of a gray hematite, $\mathbf{b}$ blue hematite, $\mathbf{c}$ laminated ore, $\mathbf{d}$ lateritic ore, and e banded hematite quartzite (BHQ)

amount of iron content in the ore sample; the width of absorption spectrum increases with decreasing the concentration of iron oxide. Gray hematite has shown a strong absorption depth at $905.25 \mathrm{~nm}$ and width 0.334146 , whereas BHQ showed absorption depth at $872.53 \mathrm{~nm}$ and width 0.453543 . Spectral parameters of various hematite ore classes and their iron content values are presented in Table 3.

\subsection{Field spectra}

The utmost significant step in this study is to collect the spectra in the field as the study area was hilly terrain and inaccessible due to other local conditions. Field spectroscopy measures the reflectance properties of rocks, vegetation, soil, and other objects under natural environmental
Table 3 Geochemistry and respective spectral parameters of various hematite ore samples

\begin{tabular}{|c|c|c|c|c|c|}
\hline \multirow[t]{3}{*}{ Sample no. } & \multirow[t]{3}{*}{$\begin{array}{l}\text { Sample } \\
\text { name }\end{array}$} & \multirow{2}{*}{\multicolumn{2}{|c|}{$\begin{array}{l}\text { Spectral param- } \\
\text { eters } \\
\text { Iron absorption } \\
\text { features }\end{array}$}} & \multirow{2}{*}{\multicolumn{2}{|c|}{$\begin{array}{l}\text { Geochemical } \\
\text { analysis } \\
\text { Fe \% }\end{array}$}} \\
\hline & & & & & \\
\hline & & Depth & Width & $\begin{array}{l}\text { Geochem- } \\
\text { istry }\end{array}$ & XRF \\
\hline 1 & $\begin{array}{l}\text { Gray hema- } \\
\text { tite }\end{array}$ & 905.25 & 0.334146 & 68.5 & 68.4 \\
\hline 2 & $\begin{array}{l}\text { Blue hema- } \\
\text { tite }\end{array}$ & 895.44 & 0.361492 & 67.2 & 67.3 \\
\hline 3 & $\begin{array}{l}\text { Laminated } \\
\text { ore }\end{array}$ & 892.32 & 0.381354 & 64.5 & 64.6 \\
\hline 4 & Lateritic ore & 865.35 & 0.395421 & 62.2 & 62.3 \\
\hline 5 & $\mathrm{BHQ}$ & 872.53 & 0.453543 & 32.6 & 32.5 \\
\hline 6 & $\mathrm{BHQ}$ & 872.53 & 0.443543 & 31.9 & 32.1 \\
\hline 7 & $\begin{array}{l}\text { Gray hema- } \\
\text { tite }\end{array}$ & 905.25 & 0.332142 & 68.2 & 68.2 \\
\hline 8 & $\begin{array}{l}\text { Blue hema- } \\
\text { tite }\end{array}$ & 895.44 & 0.365492 & 67.5 & 67.1 \\
\hline 9 & $\begin{array}{l}\text { Laminated } \\
\text { ore }\end{array}$ & 892.32 & 0.392354 & 63.8 & 63.7 \\
\hline 10 & Lateritic ore & 865.35 & 0.398421 & 61.2 & 61.4 \\
\hline 11 & $\mathrm{BHQ}$ & 872.53 & 0.443253 & 33.1 & 32.8 \\
\hline 12 & $\begin{array}{l}\text { Gray hema- } \\
\text { tite }\end{array}$ & 905.25 & 0.324152 & 67.9 & 67.5 \\
\hline 13 & $\begin{array}{l}\text { Blue hema- } \\
\text { tite }\end{array}$ & 895.44 & 0.372382 & 66.8 & 66.7 \\
\hline 14 & $\begin{array}{l}\text { Laminated } \\
\text { ore }\end{array}$ & 892.32 & 0.384321 & 64.2 & 64.5 \\
\hline 15 & Lateritic ore & 865.35 & 0.378432 & 62.1 & 62.3 \\
\hline
\end{tabular}

conditions. Spectral signatures of different types of hematite ores are collected using the spectroradiometer (SVC HR1024) model in visible, near-infrared, and shortwave infrared regions of the electromagnetic spectrum at a bandwidth of $10 \mathrm{~nm}$ at 15-degree angular fields of view (FOV). Field spectra are processed to improve the signalto-noise ratio and resampled with an interval of $5 \mathrm{~nm}$. Since field spectra are collected in the natural environment, it is crucial to remove some of the bands which belong to temperature drift and water vapor absorption before further analysis. The spectroradiometer is structured with different characteristic variations in sensor sensibility, which is utilized in diverse temperature environments. The temperature drift correction is applied at $1001 \mathrm{~nm}$ wavelength because of field spectra collected at different temperature conditions [18]. During the collection of field spectra, water vapor absorption bands arise at wavelength regions of 1350-1460 nm, 1790-1960 nm, and 2350-2500 nm due to atmospheric effects [15]; a correction is applied to eliminate these bands. Field signature 
contains self-generated noise; hence, appropriate filter is applied to smoothen the spectra. Savitzky-Golay smoothing filter has generated high-accuracy output [19]. Field spectra and photographs of various hematite ore minerals are shown in Fig. 7.

\subsection{Spectral analysis}

Matching of image spectra and field spectra is done using an absorption feature-based method known as the spectral feature fitting method. This technique is established by Clark [20]. These techniques work on continuum-removed reflectance spectra. Continuum removal is a mathematical function applied to isolate the authentic absorption features of iron ore mineral pixels from hyperspectral imagery [21]. Spectral feature fitting uses a continuum-removed unknown spectra which are compared with continuum reference spectra of known mineralogy and also produced RMS error image for each endmember to calculate RMS error. A least-square fit is calculated band by band between every reference spectra and the continuumremoved unknown spectra. Low RMS error indicates a high similarity between the field spectrum and the shape of the image spectrum. The similarity between the image spectra and reference spectra is shown by the fit image which is generated by measuring a ratio between scale image and RMS error image. Prominent absorption features are identified between the wavelengths of $750 \mathrm{~nm}$ and1100nm for oxide minerals (hematite) [22] (Fig. 8). Correlation and comparison of image spectra with field spectra of various hematite ores are also done using spectral feature fitting, SAM, and binary encoding (BE). These techniques are robust and most frequently used spectral matching techniques. All the techniques show acceptable matching scores (Table 4), and it is observed that image spectra are ideally matched with field spectra (Fig. 9). Therefore, it can be believed that there is a possibility to map the different types of hematite ores after deriving appropriate spectral parameters from the imagery. The image spectra extracted through spectral analysis techniques are used as endmembers for the classification of the data. A statistical spectral feature fitting technique was also applied to measure the similarity between image and field spectra in the form of RMS error. The resultant RMS errors of gray hematite, blue hematite, laminated ore, lateritic ore, and banded hematite quartzite are $<0.317,<0.358,<0.393,<$ 0.401 , and $<409$, respectively. The sample, which is having a high percentage of iron content, showed a significant match with field spectra. With an increase in the percentage of impurities in the sample, RMSE also increased slightly (Fig. 10). The result of this is used to assess the mapping correctness of hyperspectral imagery.

\subsection{Geochemical analysis}

\subsubsection{Wet chemical analysis}

The purpose of the geochemical analysis is to identify the concentration of primary mineral $(\mathrm{Fe})$ in the ore sample, and the results are related to spectral parameters with an appropriate pixel position. Five types of ore samples were collected from fifteen locations in the mining region covered within the Hyperion image (Fig. 1). Best samples (gray hematite, blue hematite, laminated ore, lateritic ore, and banded hematite quartzite) are selected for geochemical analysis after careful inspection of all field samples. Samples are physically crushed into $1-2 \mathrm{~cm}$ pieces, eliminating deleterious material, including weathered surfaces and veins. The chipped samples are washed carefully in distilled water to remove the surface dust and are dried. All the samples are crushed to 200 mesh in an agate pulverizer mixed meticulously for homogenization and representativeness of the sample. Small samples such as minerals and meteorites are usually crushed in steel or diamond mortars and ground manually in an agate mor$\operatorname{tar}[23]$. These ore samples are subjected to wet chemical analysis. The results of the investigation revealed that four types of samples (gray hematite, blue hematite, laminated ore, and lateritic ore) showed an enormous amount of iron (Fe) of (61.2-68.5) wt\% with a considerably low level of $\mathrm{SiO}_{2}(0.6-4.4) \mathrm{wt} \%$ and $\mathrm{Al}_{2} \mathrm{O}_{3}(0.3-6.6) \mathrm{wt} \%$, respectively, whereas a sample (BHQ) showed a low amount of iron (31.9 wt\%), a moderate amount of alumina oxide $1.3 \mathrm{wt} \%$, and a high amount of silicon oxide (51.7 wt\%). Furthermore, the ore samples contain other oxides such as $\mathrm{P}_{2} \mathrm{O}_{5}, \mathrm{TiO}_{2}, \mathrm{Cr}_{2} \mathrm{O}_{3}, \mathrm{Co}_{2} \mathrm{O}_{3}, \mathrm{CuO}, \mathrm{MnO}, \mathrm{ZnO}, \mathrm{V}_{2} \mathrm{O}_{5}, \mathrm{As}_{2} \mathrm{O}_{3}, \mathrm{SO}_{3}$, $\mathrm{BaO}$, and $\mathrm{MoO}_{3}$ which exist in considerably insignificant amounts. The ore sample, which has low iron (31.9 wt\% $\mathrm{Fe}$ ), is considered as a low grade and having other impurities (about $68.1 \mathrm{wt} \%)$. Mineralogical and geochemical studies of subgrade iron ore at the Bailadila mining region have been done by G.V. Rao [24].

\subsubsection{X-ray fluorescence analysis}

The primary and trace elements of iron ore samples can be better investigated by the XRF technique [25]. The primary element $(\mathrm{Fe})$ is investigated for five types of samples collected in the field on wavelength-dispersive $X$-ray fluorescence (WD-XRF) instrument using powder pellet pressing technique. Machine calibration is subjected to the element that has to be analyzed. The primary constituents $\left(\mathrm{Fe}_{2} \mathrm{O}_{3}\right.$, $\mathrm{SiO}_{2}, \mathrm{P}_{2} \mathrm{O}_{5}, \mathrm{Al}_{2} \mathrm{O}_{3}, \mathrm{CO}_{2} \mathrm{O}_{3}, \mathrm{Cr}_{2} \mathrm{O}_{3}, \mathrm{TiO}_{2}$, and loss of ignition (LOI)) of fifteen samples of five different hematite iron ore samples are analyzed using the XRF technique. The Fe content in ore samples ranges from 32.1 wt\% to 68.4 

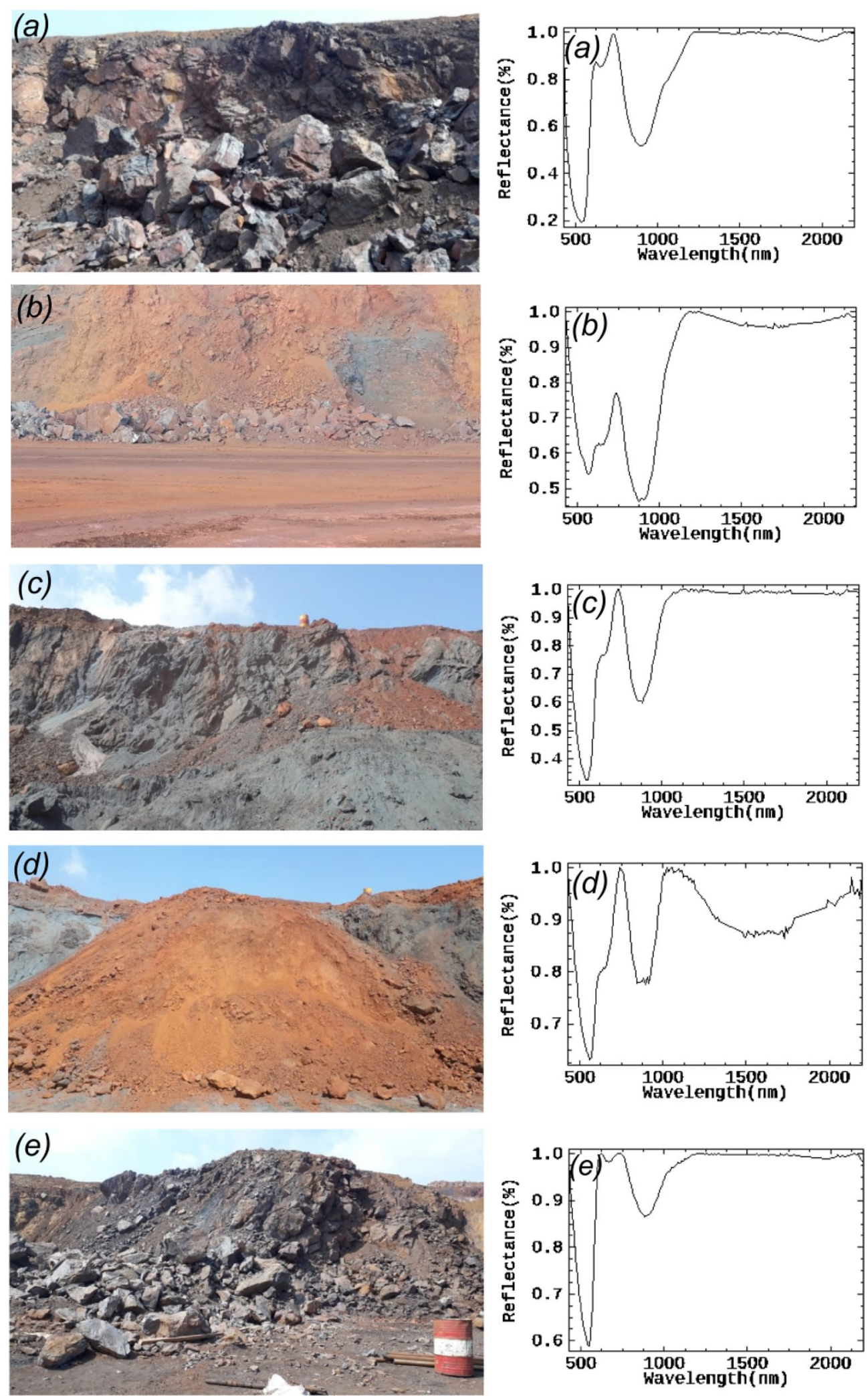

Fig. 7 Field photographs and reflectance spectra of a gray hematite, $\mathbf{b}$ blue hematite, $\mathbf{c}$ laminated ore, $\mathbf{d}$ lateritic ore, and e banded hematite quartzite (BHQ) 

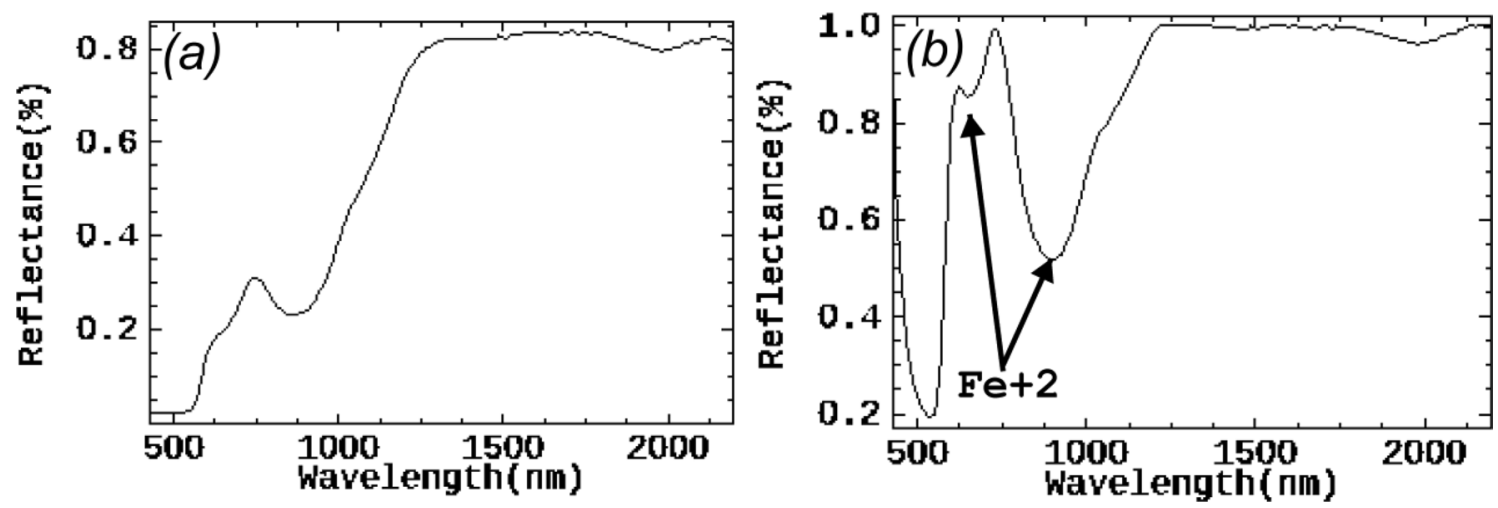

Fig. 8 Absorption features of hematite ore sample $\mathbf{a}$ before and $\mathbf{b}$ after continuum removal

Table 4 The matching score between image and field spectra

\begin{tabular}{lllll}
\hline Field spectrum & Score & SAM & SFF & BE \\
\hline Gray hematite & 1.213 & 0.204 & 0.326 & 0.990 \\
Blue hematite & 1.310 & 0.321 & 0.345 & 0.985 \\
Laminated ore & 1.333 & 0.336 & 0.367 & 0.975 \\
Lateritic ore & 1.364 & 0.382 & 0.418 & 0.954 \\
$\begin{array}{l}\text { Banded hematite } \\
\text { quartzite }\end{array}$ & 1.387 & 0.413 & 0.432 & 0.924 \\
\hline
\end{tabular}

wt\%. Primary element ( $\mathrm{Fe}$ ) found during XRF analysis is shown in Table 3.

\subsection{Correlating geochemical and spectral parameters}

Geochemical analysis of five types of hematite ore samples covered within the Hyperion image is performed to relate with their appropriate pixel locations. A standard operating procedure is followed to analyze the relationship between spectral and corresponding geochemical parameters of the ore samples [26]. Analysis of spectral curves extracted from the image discloses that the intensity of absorption increases with increasing iron content in the near-infrared region. The strength of absorption also varies with clay content present in the sample [27]. Therefore, absorption features in the near-infrared region can be used to describe the iron oxide mineral content present in the field ore samples based on the significant spectral constraints like the position of absorption features, depth, and width [22]. During analysis, it is observed that the depth of absorption increases in the near-infrared region with increasing iron concentration. The sample having an iron content of more than $60 \%$ is more sensitive to absorption. Hence, even for a small raise in iron content, there is a significant rise in depth of absorption. During the formation of iron oxides, higher energy is required for the phenomena of electronic transition [28]. It is observed that the correlation is relatively strong; the association between spectral parameters derived from the image and iron concentration is well recognized by this work. Empirical models were established based on precise correlations, such as those observed between iron content in the hematite ore samples and the depth of NIR absorption feature of the matching hematite ore sample which has the finest correlation $\left(R^{2}=0.843\right)$ as shown in Fig. 11 a. This directs that for a rise in the mass of iron from 14 to $60 \%$, the depth of NIR absorption increases steadily and the strength of absorption is not sensitive to the increasing iron mass. However, for an increase from 60 to $70 \%$, the strength of absorption is very subtle, i.e., even for a small increase in iron content; there is a substantial rise in the depth of absorption. The phenomenon of electronic transition during the formation of iron oxide perhaps requires higher energy even for a small increase in the iron content beyond $60 \%$ [28]. The width of the near-infrared absorption feature of the matching hematite ore sample has a negative correlation $\left(R^{2}=0.812\right)$ as shown in Fig. 11b. It is evident that when the depth of absorption increases, the absorption feature inclines to become narrower and the width becomes smaller. While an increase in depth of the absorption feature is the reason, an increase in the width of the absorption feature is the effect. Thus, an exponential relationship similar to the depth of NIR absorption is seen in the case of the width of NIR absorption. These relationships suggest that we can attain a quantitative and qualitative description of the relationship between iron content in the hematite ores and the different spectral parameters. This description draws a correlation from the studies of Dawson and Curran [29]. The geochemistry and respective spectral parameters of various hematite ore samples are shown in Table3. 

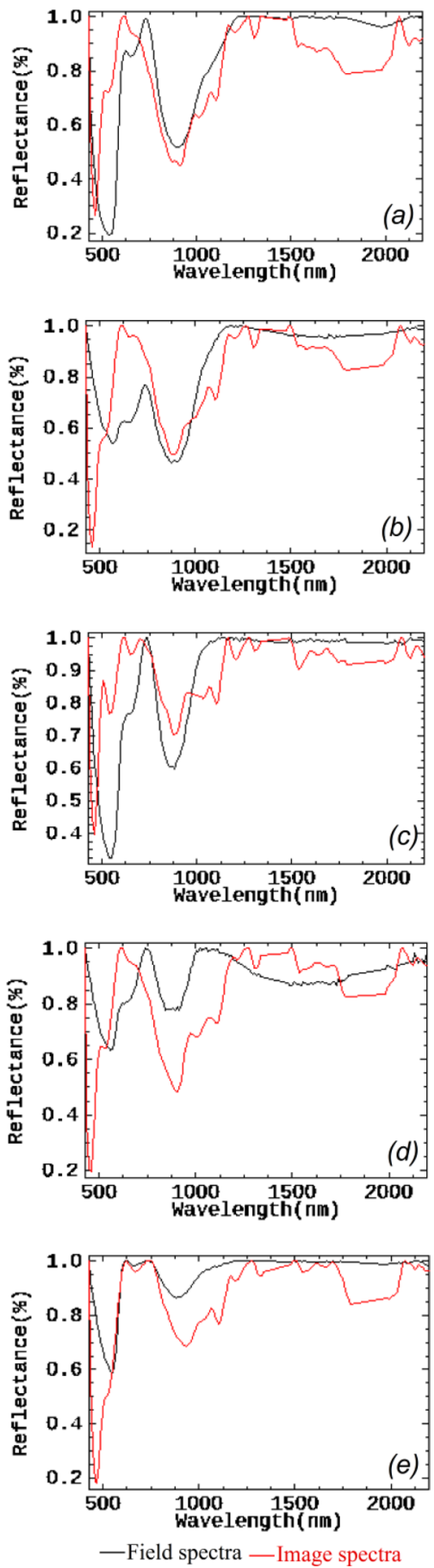

Fig. 9 Comparison of image and field spectra of a gray hematite, $\mathbf{b}$ blue hematite, $\mathbf{c}$ laminated ore, $\mathbf{d}$ lateritic ore, and e banded hematite quartzite (BHQ)

\subsection{Spectral angle mapper (SAM)}

SAM computes the spectral similarity between the image spectrum and the reference spectrum taken either from the laboratory or reflectance spectrum collected from the field at natural atmospheric conditions [30]. SAM assumes

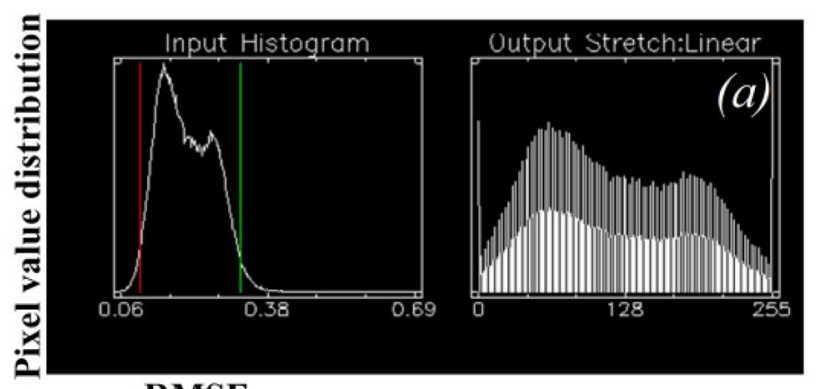

RMSE
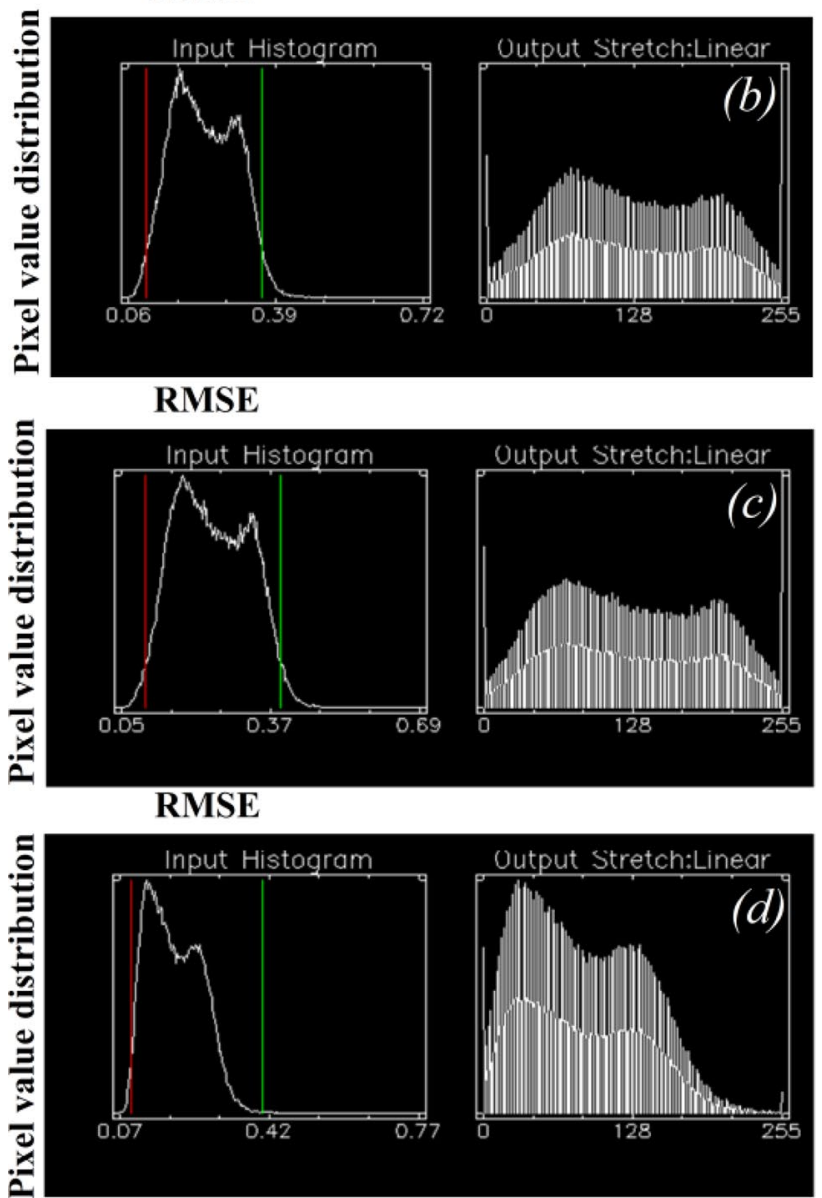

RMSE

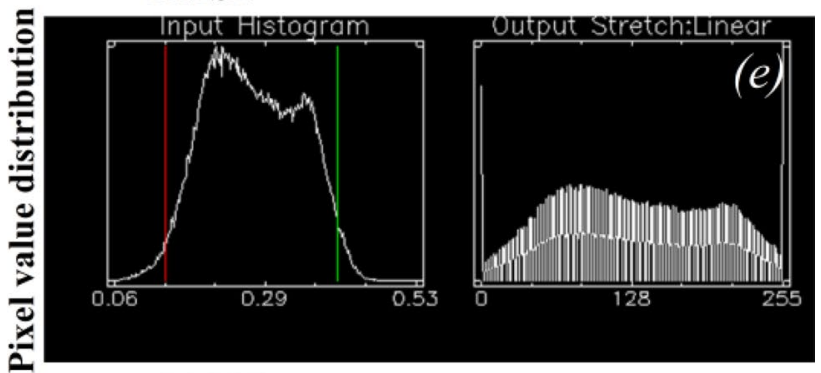

RMSE

Fig. 10 The RMS error and histogram of a gray hematite, $\mathbf{b}$ blue hematite, c laminated ore, d lateritic ore, and e banded hematite quartzite

\section{SN Applied Sciences}



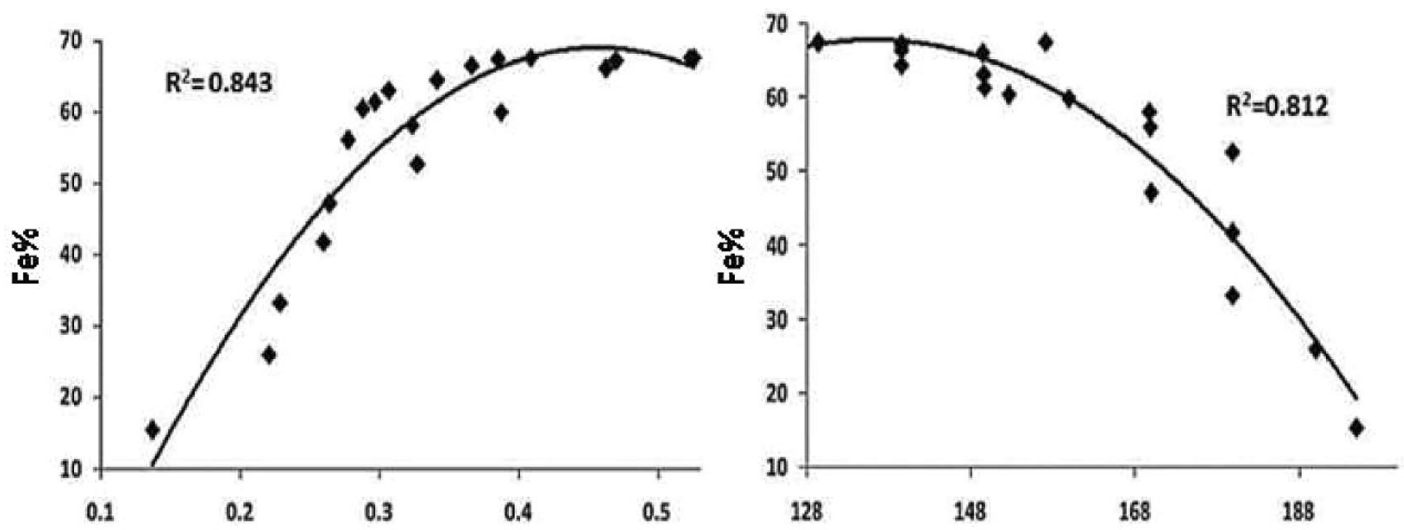

(a) Depth of NIR absorption feature(graph units) (b) Width of NIR absorption feature(graph units)

Fig. 11 a Empirical models relating Fe\% in the hematite iron ores and depth of near-infrared absorption feature and $\mathbf{b}$ model relating Fe\% in the iron ore samples and width of NIR absorption feature

that the data have been converted to apparent reflectance. While computing the SAM, each spectrum is considered as a vector in $\mathrm{n}$-dimensional space [31, 32]. SAM measures the angular difference between image spectra and reference spectra for each pixel in radians represented in mathematical equation (Eq. (2)) [33]. The smaller the divergence, the higher the similarity, and the enormous difference means low similarity between the test (image spectrum) and the reference spectrum.

$$
\cos \varphi=\frac{\sum_{i=1}^{n} t_{i} r_{i}}{\sqrt{\sum_{i=1}^{n} t_{i}^{2}} \sqrt{\sum_{i=1}^{n} r_{i}^{2}}}
$$

where $\varphi$ is the spectral angle, $t$ refers to the test spectrum, $r$ denotes the reference spectrum, and $n$ denotes the higher number of bands. SAM classification is an automated, robust technique since it reduces the impact of shadiness issues to emphasize the image spectral features [34]. For every reference spectrum selected for the investigation of a Hyperion image, the spectral angle $\varphi$ is calculated, which is meant for each spectrum of the image. This value (in radians) is allotted to the matching pixel in the SAM output image. The image spectra were endmember (Fig. 6) spectra extracted from Hyperion data. In this study, different types of hematite ore minerals conform to the geological background of the study area selected from the field spectral library such as different types of hematite ores associated with iron. The reference spectra for SAM were obtained after spectral matching between image spectra and field spectra [35]. Resampling of field spectra was done to ensure the resolution of endmember spectra consistent with field spectra. The SAM algorithm is utilized to generate a detailed mineral map. The numbers of reference spectrum or endmember are equal to the number of outputs. The detailed classified map showed that the most excellent match at every image spectra (pixel) for every endmember appears for the actual angular distance between each image and the reference spectrum. The SAM classification map for Hyperion imagery shows good results for discrimination of types of hematite ores in the study area, because the thickness of iron ores is relatively vast and extends for several kilometers long. The probability of misclassification is very minimal because of no other mixed pixels, area exposure, and high spectral dimensions of the data. The classified iron ores map of the study area is shown in Fig. 12. The output of the geochemical analysis is correlated with the hematite ore minerals of corresponding locations assessed by spectral angle mapper. The finest match $\left(R^{2}=0.814\right)$ is observed between iron content in the hematite ore samples and iron content estimated by spectral angle mapper (Fig. 13).

\subsubsection{Accuracy assessment}

The accuracy of the detailed map is assessed through the confusion matrix method. There are two methods to evaluate the accuracy of the results, i.e., through confusion matrix and the Kappa coefficient. In this study, the overall accuracy of the classified image is about $88.19 \%$ and the Kappa coefficient is 0.81 (Table 5).

\section{Conclusions}

This research work illustrates the practicability of using Hyperion imagery for mapping various types of hematite ores in hilly and inaccessible locations. The finest processed image spectra assisted in identifying the prominent absorption features $(750-1100 \mathrm{~nm})$ related to iron 


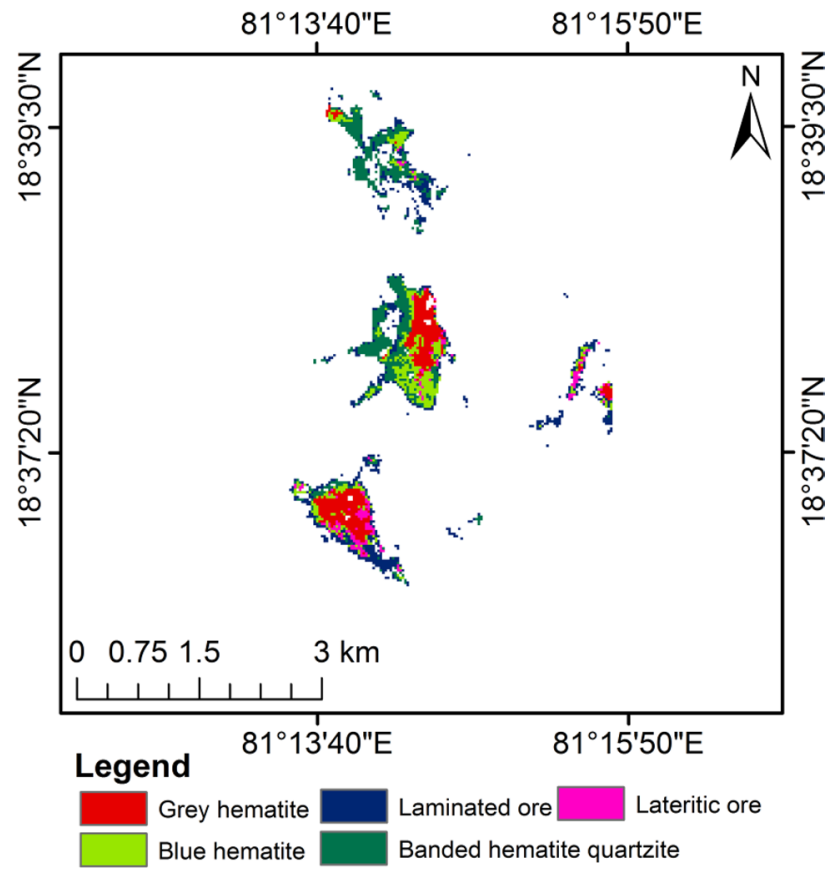

Fig. 12 The classified map of hematite ore classes

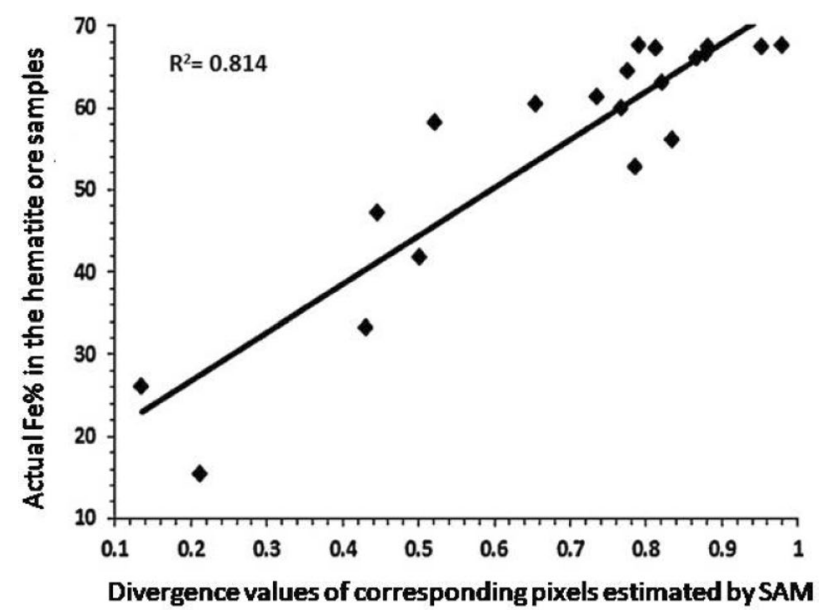

Fig. 13 Correlation between $\mathrm{Fe} \%$ in hematite ore samples and fraction of pixel values estimated by SAM

oxide minerals. Matching between image and field spectra through spectral feature fitting technique showed the best correlation. Prominent spectral absorption features of iron ore at a particular wavelength, location, and geochemical analysis of iron ore samples showed a good association. The depth and width of the absorption features of spectra are increasing with the increasing amount of iron content. The depth of absorption is increasing significantly, even a minute increase in the concentration of iron content in the sample. SFF is a robust method to compare the similarity
Table 5 Overall accuracy of classified map

\begin{tabular}{llll}
\hline \multicolumn{3}{l}{ SAM classification } & \\
\hline Category & $\begin{array}{l}\text { Producer } \\
\text { accuracy (\%) }\end{array}$ & $\begin{array}{l}\text { User accu- } \\
\text { racy (\%) }\end{array}$ & Overall accuracy (\%) \\
\hline Gray hematite & 92.20 & 91.14 & 88.19 \\
Blue hematite & 91.11 & 88.24 & \\
Laminated ore & 88.34 & 86.21 & \\
Lateritic ore & 86.21 & 87.31 & \\
$\begin{array}{c}\text { Banded hema- } \\
\text { tite quartzite }\end{array}$ & 84.54 & 86.62 & \\
\hline
\end{tabular}

between field and image spectra of Hyperion data. Further, the classified map of Hyperion data resulted from the spectral angle mapper algorithm. RMSE values show the exceptional matching between image and field spectra which leads to an increase in the classification accuracy. The confusion matrix and the value of the Kappa coefficient show the accuracy of the classified output.

Acknowledgment The authors convey their sincere gratitude to NMDC officials for their assistance during the fieldwork and the head of the division for his encouragement to carry out this study. The authors are also thankful to colleagues and friends for their technical help throughout this study.

\section{Compliance with ethical standards}

Conflict of interest The author declared that there is no conflict of interest.

Open Access This article is licensed under a Creative Commons Attribution 4.0 International License, which permits use, sharing, adaptation, distribution and reproduction in any medium or format, as long as you give appropriate credit to the original author(s) and the source, provide a link to the Creative Commons licence, and indicate if changes were made. The images or other third party material in this article are included in the article's Creative Commons licence, unless indicated otherwise in a credit line to the material. If material is not included in the article's Creative Commons licence and your intended use is not permitted by statutory regulation or exceeds the permitted use, you will need to obtain permission directly from the copyright holder. To view a copy of this licence, visit http://creativecommons .org/licenses/by/4.0\%.

\section{References}

1. Zhang Ting-ting, Liu Fei (2012). Application of hyperspectral remote sensing in mineral identification and mapping. Proceedings of 2012 2nd international conference on computer science and network technology. doi: https://doi.org/10.1109/ ICCSNT.2012.6525900

2. Pour AB, Hashim M (2014) ASTER, ALI and Hyperion sensors data for lithological mapping and ore minerals exploration. Springer Plus. https://doi.org/10.1186/2193-1801-3-130 
3. Mahesh Kumar T et al (2020) Identification of hydrothermal altered/weathered and clay minerals through airborne AVIRISNG hyperspectral data in Jahajpur, India. Heliyon. https://doi. org/10.1016/j.heliyon.2020.e03487

4. Kiran Raj $S$ et al (2015) Iron oxides mapping from EO-1 hyperion data. Geol Surv India 86:717-725

5. Townsend TE (1987) Discrimination of iron alteration minerals in visible and near-infrared reflectance data. J Geophys Res 92:1441-1454

6. Aliyu Jaafar A et al (2018) Identification of hydrothermal alteration minerals associated with geothermal system using ASTER and Hyperion satellite data: a case study from Yankari Park, NE Nigeria. Geocarto Int. https://doi.org/10.1080/10106 049.2017 .1421716

7. Farifteh J et al (2013) Mapping spatial variations of iron oxide by-product minerals from EO-1 Hyperion. Int J Remote Sens 34:682-699. https://doi.org/10.1080/01431161.2012.715776

8. Crookshank H (1963) Geology of Southern Bastar and Jeypore from the Bailadila range to Eastern Ghats. Memoirs Geol Surv India Memoir 87:96-108

9. Verma R (2019) Appraisal of crustal contamination in Southern Bastar Mafic Dykes in Chattisgarh, India. Open J Geology 9:988-1003. https://doi.org/10.4236/ojg.2019.913101

10. Verma R, Kumar S, Singh TN (2004) Suitability of Bastar Granitoids as construction material. Recent Res Econ Geol 2:85-92

11. Ramakrishnan M (1990) Crustal development in southern Bastar central Indian craton. J Geol Surv India 28:44-66

12. Taner San B, Lutfi Suzen M (2011) Evaluation of cross-track illumination in EO-1 Hyperion imagery for lithological mapping. Int J Remote Sens 32(22):7873-7889. https://doi.org/10.1080/01431 161.2010 .532175

13. Scheffler D, Karrasch $P$ (2014) Destriping of hyperspectral image data: an evaluation of different algorithms using EO-1 Hyperion data. J Appl Remote Sens. https://doi.org/10.1117/1.JRS.8.08364 5

14. San BT, Suzen ML (2010) Evaluation of different atmospheric correction algorithms for EO-1 Hyperion imagery. International Archives of the photogrammetry remote sensing and spatial information sciences, XXXVIII, Part 8, Kyoto Japan

15. Staenz K et al (2002) Radiative transfer codes applied to hyperspectral data for the retrieval of surface reflectance. ISPRS J Photogramm Remote Sens. https://doi.org/10.1016/S0924 $-2716(02) 00121-1$

16. Gao BC et al (2009) Atmospheric correction algorithms for hyperspectral remote sensing data of land and ocean. Remote Sens Environ 113:S17-S24. https://doi.org/10.1016/j. rse.2007.12.015

17. Clark RN, Roush TL (1984) Reflectance spectroscopy: quantitative analysis techniques for remote sensing applications. J Geophys Res 89:6329-6340. https://doi.org/10.1029/JB089iB07p 06329

18. Lenhard K (2015) Improving the calibration of airborne hyperspectral sensors for earth observation. Institute of Geography, UZH dissertations. http://opac.nebis.ch/ediss/20152446.pdf

19. Faun T, William P (1998) Derivative analysis of hyperspectral data. Remote Sens Environ 66:41-51. https://doi.org/10.1016/ S0034-4257(98)00032-7

20. Roger N, Clark et al. (1990). Material absorption and depth mapping of imaging spectrometer data using a complete band shape least-squares fit with library reference spectra. Proceeding of the second airborne visible/infrared imaging spectrometer (AVIRIS) Workshop
21. van der Freek M (2004) Analysis of spectral absorption features in hyperspectral imagery. Int J Appl Earth Obs Geoinf 5:55-68. https://doi.org/10.1016/j.jag.2003.09.001

22. Magendran T, Sanjeevi S (2014) Hyperion image analysis and linear spectral unmixing to evaluate the grades of iron ore in parts of Noamundi, Eastern India. Int J Appl Earth Obs Geoinf 26:413-426. https://doi.org/10.1016/j.jag.2013.09.004

23. Atherton MP, Brotherton MS, Raiswell R (1971) A comparison of automatic and manual wet chemical analysis of rocks. Chem Geol. https://doi.org/10.1016/0009-2541(71)90013-1

24. Rao GV et al (2018) Mineralogy and geochemistry of sub-grade iron ore sample from deposit no.5 of Bacheli complex and their implications on beneficiation. J Appl Geochem 20(2):229-238

25. Revenko AG (2002) X-ray fluorescence analysis of rocks, soils and sediments. X-Ray Spectrom 31:264-273. https://doi. org/10.1002/xrs.564

26. Bonifazi G (1995) Digital multispectral techniques and automated image analysis procedures for industrial ore modelling. Miner Eng 8(7):779-794. https://doi.org/10.1016/08926875(95)00039-S

27. Clark RN (1999) Spectroscopy of rocks and minerals, and principles of spectroscopy. In: Rencz AN (ed) Manual of remote sensing for the earth sciences. Wiley, New York

28. Drury SA (1993) A review of image interpretation in geology. London Chapman and Hall. 2nd edition. https://doi.org/https ://doi.org/10.1080/01431169508954438

29. Dawson TP, Curran PJ (1998) Technical note a new technique for interpolating the reflectance red edge position. Int J Remote Sens 19(11):2133-2139. https://doi.org/10.1080/0143116982 14910

30. Roberta HY, Alexander FH, Goetz, Joe WB (1992) Discrimination among semi-arid landscape endmembers using the Spectral Angle Mapper (SAM) algorithm. JPL, summaries of the third annual JPL airborne geoscience workshop. Volume 1: AVIRIS workshop

31. Kruse FA et al (1993) The Spectral Image Processing System (SIPS) interactive visualization and analysis of imaging spectrometer data. Remote Sens Environ 44:145-163

32. Van Der Meer F, Vazquez-Torres M, Van Dijk PM (1997) Spectral characterization of ophiolite lithologies in the Troodos Ophiolite complex of Cyprus and its potential in prospecting for massive sulphide deposits. Int J Remote Sens 18:1245-1257. https://doi. org/10.1080/014311697218395

33. Osmar Abílio de Carvalho Jr, Paulo Roberto Meneses (2000) Spectral Correlation Mapper (SCM): an improvement on the Spectral Angle Mapper (SAM). 9th JPL airborne earth science conference.

34. Shuang Huang, Sheng-Bo Chen, Yuan-Zhi Zhang (2018) Comparison of altered mineral information extracted from ETM+, ASTER and hyperion data in Águas Claras iron ore, Brazil. IET Image Processing

35. van der Meer F (2005) The effectiveness of spectral similarity measures for the analysis of hyperspectral imagery. Int J Appl Earth Obs Geoinform 8:3-17. https://doi.org/10.1016/j. jag.2005.06.001

Publisher's Note Springer Nature remains neutral with regard to jurisdictional claims in published maps and institutional affiliations. 